\title{
H3C2 wt Allele
}

National Cancer Institute

\section{Source}

National Cancer Institute. H3C2 wt Allele. NCl Thesaurus. Code C101733.

Human $\mathrm{H} 3 \mathrm{C} 2$ wild-type allele is located in the vicinity of $6 \mathrm{p} 22.1$ and is approximately $1 \mathrm{~kb}$ in length. This allele, which encodes histone H3.1 protein, plays a role in the modulation of chromatin structure. 